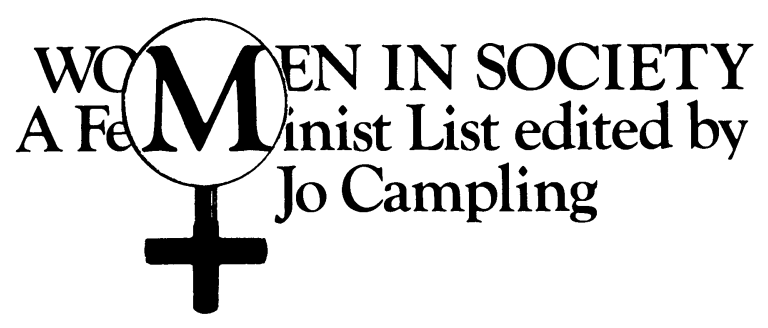

editorial advisory group

Maria Brenton, University College, Cardiff; Phillida Bunckle, Victoria University, Wellington, New Zealand; Miriam David, Polytechnic of the South Bank; Leonore Davidoff, University of Essex; Janet Finch, University of Lancaster; Jalna Hanmer, University of Bradford; Beverley Kingston, University of New South Wales, Australia; Hilary Land, University of Bristol; Diana Leonard, University of London Institute of Education; Susan Lonsdale, Polytechnic of the South Bank; Jean O'Barr, Duke University, North Carolina, USA; Arlene Tigar McLaren, Simon Fraser University, British Columbia, Canada; Jill Roe, Macquarie University, Australia; Hilary Rose, University of Bradford; Pat Thane, Goldsmiths' College, University of London; Jane Thompson, University of Southampton; Clare Ungerson, University of Kent at Canterbury; Judy Walkowitz, Rutgers University, New Jersey, USA.

The 1970s and 1980s have seen an explosion of publishing by, about and for women. This new list is designed to make a particular contribution to this process by commissioning and publishing books which consolidate and advance feminist research and debate in key areas in a form suitable for students, academics and researchers but also accessible to a broader general readership.

As far as possible books will adopt an international perspective incorporating comparative material from a range of countries where this is illuminating. Above all they will be interdisciplinary, aiming to put women's studies and feminist discussion firmly on the agenda in subject-areas as disparate as law, physical education, art and social policy. 


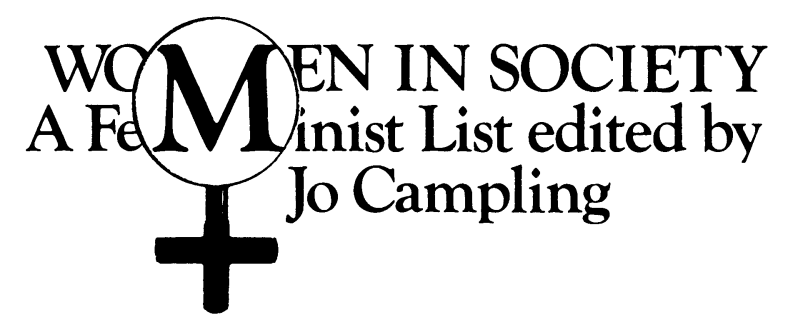

Published

Jenny Beale Women in Ireland: voices of change

Leonore Davidoff and Belinda Westover (editors) Our Work, Our Lives, Our Words: women's history and women's work

Diana Gittins The Family in Question: changing households and familiar ideologies

Frances Heidensohn Women and Crime

Muthoni Likimani (Introductory Essay by Jean O'Barr)

Passbook Number F.47927: women and Mau Mau in Kenya Rosemary Ridd and Helen Callaway (editors) Caught Up in

Conflict: women's responses to political strife

Clare Ungerson (editor) Women and Social Policy: a reader

\section{Forthcoming}

Sheila Allen and Carol Wolkowitz Homeworking: myths and realities

Maria Brenton Women and Old Age

Sheila Button Women and Local Politics

Angela Coyle and Jane Skinner Women and Work: positive action for equal opportunities

Gillian Dalley Ideologies of Caring

Jennifer Hargreaves Women and Sport

Annie Hudson Troublesome Girls: adolescence, femininity

and the state

Ursula King Women and Spirituality

Susan Lonsdale Women and Disability

Sharon MacDonald, Pat Holden and Shirley Ardener Images

of Women in Peace and War

Jan Pahl Marriage and Money

Lesley Rimmer Women's Family Lives

Deborah Valenze The Other Victorian Women

Janet Wolff The Art of Women 


\title{
Women in Ireland
}

\author{
Voices of Change
}

\section{Jenny Beale}

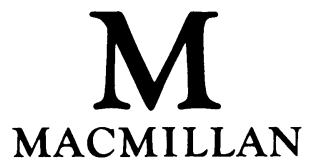


(C) Jenny Beale 1986

Softcover reprint of the hardcover 1st edition 1986 978-0-333-36896-1

All rights reserved. No reproduction, copy or transmission of this publication may be made without written permission.

No paragraph of this publication may be reproduced, copied or transmitted save with written permission or in accordance with the provisions of the Copyright Act 1956 (as amended).

Any person who does any unauthorised act in relation to this publication may be liable to criminal prosecution and civil claims for damages.

First published 1986

Published by

MACMILLAN EDUCATION LTD

Houndmills, Basingstoke, Hampshire RG21 2XS

and London

Companies and representatives

throughout the world

Photoset in Times by

CAS Typesetters, Southampton

British Library Cataloguing in Publication Data

Beale, Jenny

Women in Ireland-(Women in society)

1. Women-Ireland-Social conditions

I. Title II. Series

305.4'2'09417 HQ1600.3

ISBN 978-0-333-36897-8

ISBN 978-1-349-18378-4 (eBook)

DOI 10.1007/978-1-349-18378-4 
For Pat, in sisterhood 


\section{Contents}

Preface

viii

Acknowledgements

$\mathbf{x}$

Editor's Introduction by Jo Campling

$\mathrm{xi}$

1 Introduction: Women and the Family

2 Maidens and Myths: Women in Rural Life

3 Of Housewives, Mothers and Mary

4 Marriage: a New Partnership?

5 Sexuality I: A Matter of Choice

6 Sexuality II: Contraception and Abortion

7 Girls in School

8 Working for a Living

9 Finding a Voice: Women in the Church

10 Towards Equality: Progress and Problems

Appendix: A Social Profile of the Interviewees

Notes and References

Bibliography

Index 


\section{Preface}

This book is about the extensive changes in the lives of women in the Republic of Ireland during the past twenty to thirty years. During that time, Ireland has developed from a predominantly rural country into an industrialising member-state of the European Economic Community. Rural life has all but disappeared, to be replaced by an urban, materialist culture and a class structure more akin to that in other Western European countries. Many aspects of these social and economic changes are reflected in women's lives. Women now living a relatively sophisticated city-based existence, whose daughters watch the latest videos and go to discos, can recall childhood memories of rural poverty and overcrowding. Many women no older than forty had to leave their jobs on marriage and had no access to contraception, whereas their daughters expect equal opportunities at work and take the local family planning clinic for granted.

Women in both the countryside and towns have been affected by the rapid pace of this transition from rural to urban life. Yet the transition has been neither easy nor complete. The old and the new frequently rub shoulders, and there is tension between them. Issues relating to the changing status of women have acted as focal points for controversy over the wider changes in values and attitudes in Irish society. This is still apparent in the 1980 s as debates about divorce, contraception and the family continue unabated.

Because relatively little has been written about women in Ireland (though there has recently been a welcome expansion in women's writing and publishing), there is a danger that women's experiences of this period could be lost. This book is intended to be a contribution towards averting that danger. I set out to describe the background to the transition in women's lives, and to reflect the changing experience of women. The interview material in the book is taken from taped conversations with twenty-seven women of different ages and from a variety of backgrounds. Some of the 
women live in Dublin, others are from smaller towns and country areas, particularly in the west. A social profile of the interviewees appears in the Appendix. The interviews do not make up a formal survey, but are intended to illustrate a range of different experiences in a way that statistics and information are unable to do.

Every book is coloured by the author's own background and attitudes, in this case by my situation as an Englishwoman living and working in Ireland. I write in a spirit of sisterhood with Irish women, and hope that the book will be of interest to all those who care about the position of women in Irish society.

The term 'Ireland' is used to refer to the twenty-six counties of the Republic of Ireland unless otherwise indicated. Although I am aware of the problems associated with limiting the scope of the text to the Republic, trying to include the very different traditions of women in the North in a book of this size would present even greater difficulties. I have, however, included some comparative material on the position of women in Northern Ireland. 


\section{Acknowledgements}

I am very grateful to all the women who agreed to be interviewed and who talked so freely about themselves. I also owe a great deal to the women in my classes over the past few years. I have learned an enormous amount through my work with them in adult education and training. I would also like to thank Beth Brownfield, Anne Coughlan, Bernie Divilly, Betty Gosling, Kathleen Lough, Rosemary Cullen Owens and Tony Varley for their comments on the first draft. Pat Farrell helped me to develop my ideas, and both she and Colin Brown provided great support throughout. A big thank you to them both. Finally, my thanks to Jo Crampling for her encouragement and for her belief that women have something important to say.

J. B. 


\section{Editor's Introduction}

In 1983 I contacted Jenny Beale to write a book on women and trade unions for Women and Society, only to discover that she was then living and working in the Republic of Ireland. We met, and it became clear that she really wanted to write a book about women in Ireland today. At that time, she was teaching courses for married women who wanted to return to work, and some classes in Women's Studies. This work gave her a strong sense of the rapid changes that had occurred in women's lives in Ireland and personal contact with many women who had lived through them. Some women had spent their childhood in rural poverty and others had emigrated to Britain to find work and had returned to Ireland in the 1970 s, as so many did. Then there were the younger women who had experienced none of this, but who had modern, urban lifestyles.

Many of the changes are very recent: as late as the 1950s many people in the west of Ireland were living peasant lives; the industrialisation of much of the Republic only took place in the 1960s; and the marriage bar in certain occupations was not removed until 1973. Add to this the fact that many of the most controversial issues in Irish society such as contraception, divorce and the rights of the family are essentially about the role and rights of women, and it becomes clear that something very important has been happening to women which deserves to be recorded. This book does just that. It is intentionally wide-ranging in scope as it is the first book to give an overview of women's experiences in the period since about 1960.

The central themes of the book revolve around the family and sexuality, both of which are connected with the Roman Catholic Church and its enormously important influence, not only on the structures of Irish society, but also on people's deepest emotions and ways of looking at the world. The book does not, however, fall into the trap of being anti-Church, but includes the experiences of Christian women. A particularly interesting and original section of the book explores the changing lives of nuns and the exciting new ways in which some of them are interpreting their roles. 


\section{xii Editor's Introduction}

Through the interview material in the book Irish women speak for themselves, and give the text a direct and authentic tone that is a pleasure to read. It is a book in the emerging feminist tradition in that the author uses women's descriptions of their experiences to illustrate themes and to fire off thoughts and reflections in the reader. As well as providing analysis and background information, the book captures the feelings behind the transition in ordinary women's lives. As a result it is lively and enjoyable as well as informative.

Because little has been written about women in the Republic of Ireland, people both inside and outside the country lack information about recent issues and developments. This book will help to communicate something of the reality of Irish women's situation to a wider audience, and will contribute to the understanding between women of different cultures that is so important to the women's movement internationally. 